\title{
Outcome of Pregnancies in Diabetic Mothers in Norway 1967-1976
}

\author{
J. Jervell, T. Bjerkedal, and N. Moe \\ Rikshospitalet and Medical Birth Registry of Norway, Oslo, Norway
}

\begin{abstract}
Summary. A total of 1035 births to diabetic mothers were registered in Norway during the 10 -year period 1967-1976. Perinatal mortality (from 16 weeks of gestation until 7 days after birth) decreased from 177.4 per 1000 births in $1967-68$ to 60.7 in 1975-1976; for the total population the figures were 24.1 and 18.4. During the same period the duration of gestation increased from 35.5 weeks in 1967-1968 to 37.0 weeks in 1975-1976. The numbers of small and large infants decreased: in 1967-1968 53.3\% weighed 2500-4000 grams, in 1975-1976 70.7\%. Moreover, more births took place in university clinics and regional hospitals, $38.7 \%$ in 1967-1968 and $77.1 \%$ in $1975-1976$. Malformations were $50 \%$ more common in children of diabetics. Cardiovascular and nervous system malformations accounted for this increase, being 5 times more frequent than in the general population.
\end{abstract}

Key words: Diabetic pregnancies, perinatal deaths, congenital malformations, birth weight, gestational age.

Pregnancy in diabetic women has until recently been associated with a high perinatal mortality $[1,2,3]$. Improved results have, however, been obtained at specialized clinics by a regimen of close metabolic, obstetric and neonatal supervision $[4,5,6,7]$, also in Norway [8]. The Norwegian birth registry [9], in existence since 1967, has made it possible to analyse the outcome of diabetic pregnancies in Norway, and thereby to evaluate the quality of care of these highrisk pregnancies in an unselected total population of births. Previously, a clinical study of diabetic pregnancies at Rikshospitalet, Oslo, 1970-1977 has been reported [8], these pregnancies are of course included in the present presentation.

\section{Methods}

In Norway medical personnel are required by law to complete a Medical Registration of Birth for every delivery of a fetus of 16 weeks gestation and more [9]. This registration, which is made 7 days after delivery, contains questions related to the mothers' health before and during pregnancy, to complications and interventions, and to the condition of the newborn. The forms are collected at the Medical Birth Registry where a computer file is kept of all records. Completeness of registration is checked through linkage with the civic registration of births. Survival of livebirths is updated through linkage with the offical registration of deaths. No further systematic evaluation of completeness of reporting is undertaken and no details regarding the type, severity and duration of the mothers' diabetes is recorded. For about $90 \%$ of the births to diabetic mothers, however, it was definitely stated that diabetes was present before pregnancy. Details of regimen used at various hospitals were not available through the birth registry, the regimen used at Rikshospitalet has been presented previously [8].

\section{Results}

\section{Perinatal Mortality}

During the 10-year period 1967-1976 a total of 1023 pregnancies in diabetics were registered in Norway, of which 12 resulted in twins, giving 1035 births. Of these $14.5 \%$ died perinatally. The rates of fetal and total perinatal death started to decline in 1973-1974 so reach 60.7 per 1000 births in 1975-1976 (Table 1).

A comparison of perinatal death rates at Rikshospitalet, the University clinic in Oslo, and the rest of the country is presented in Table 2 . The perinatal death rates started to decline earlier at Rikshospitalet 
Table 1. Births to diabetic mothers in Norway 1967-1976. Total number of births, fetal and perinatal deaths and rates per 1000

\begin{tabular}{llllll}
\hline Years & $\begin{array}{l}\text { Total number } \\
\text { of births }\end{array}$ & Fetal deaths & \multicolumn{2}{c}{ Total perinatal deaths } \\
\cline { 5 - 6 } & number & rate/1000 & rate/1000 \\
\hline $1967-1968$ & 186 & 22 & 118.3 & 33 & 177.4 \\
$1969-1970$ & 223 & 30 & 134.5 & 43 & 192.8 \\
$1971-1972$ & 201 & 22 & 109.5 & 27 & 169.2 \\
$1973-1974$ & 211 & 18 & 85.3 & 13 & 60.7 \\
$1975-1976$ & 214 & 12 & 56.1 & 150 & 144.9 \\
\hline $1967-1976$ & 1035 & 104 & 100.5 &
\end{tabular}

Figures includes outcome of pregnancies down to 16 weeks of gestation, and 12 twin births

Table 2. Births to diabetic mothers in Norway 1967-1976. Outcome at Rikshospitalet, the University Clinic in Oslo, and the rest of the country

\begin{tabular}{|c|c|c|c|c|c|c|}
\hline \multirow[b]{2}{*}{ Years } & \multicolumn{3}{|c|}{ Rikshospitalet } & \multicolumn{3}{|c|}{ Rest of Norway } \\
\hline & Number of & Perinatal & $\mathrm{rate} / 1000$ & Number of & Perinatal deaths & rate $/ 1000$ \\
\hline $1967-1968$ & 27 & 2 & 74.1 & 159 & 31 & 195.0 \\
\hline $1969-1970$ & 40 & 6 & 150.0 & 183 & 37 & 202.0 \\
\hline $1971-1972$ & 49 & 4 & 81.6 & 152 & 30 & 197.4 \\
\hline $1973-1974$ & 68 & 5 & 73.5 & 143 & 22 & 153.8 \\
\hline $1975-1976$ & 94 & 4 & 42.6 & 120 & 9 & 75.0 \\
\hline $1967-1976$ & 278 & 21 & 75.5 & 757 & 129 & 170.4 \\
\hline
\end{tabular}

Data from Rikshospitalet have in part been published previously [8]

Table 3. Births to diabetic mothers in Norway 1967-1976. Place of delivery

\begin{tabular}{llll}
\hline \multirow{4}{*}{ Years } & \multicolumn{2}{l}{ Percent born at: } \\
\cline { 2 - 4 } & $\begin{array}{l}\text { Rikshos- }_{\text {pitalet }^{\mathrm{a}}} \\
\text { (14.5 }\end{array}$ & $\begin{array}{l}\text { Other major } \\
\text { hospitals }^{\mathrm{b}}\end{array}$ & Other places \\
\hline $1967-1968$ & 14.2 & 61.3 \\
$1969-1970$ & 17.9 & 19.7 & 62.2 \\
$1971-1972$ & 24.4 & 30.9 & 44.8 \\
$1973-1974$ & 32.2 & 31.8 & 36.0 \\
$1975-1976$ & 43.0 & 34.1 & 22.9 \\
\hline $1967-1976$ & 26.7 & 28.1 & 45.2 \\
\hline
\end{tabular}

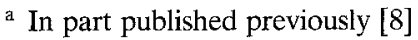

b Included births at the University Hospitals in Bergen, Trondheim and Tromsö and regional hospitals of Kristiansand and Stavanger

c All other births (at hospitals, at home or under transport to hospital)

and were consistently lower throughout the 10 year study period.

\section{Change in Place of Diabetic Births}

A committee on diabetic pregnancies in Norway in 1974 suggested that the management of these high risk pregnancies should be centralized to the University hospitals in Oslo (Rikshospitalet), Bergen, Trondheim and Tromsö, and to the country hospitals of Stavanger and/or Kristiansand. There was a definite trend in this direction during the period. In $1967-1968$ only $38.7 \%$ of the births to diabetic mothers took place at these major hospitals, while in 1975-1976 the percentage was 77.1 (Table 3).

\section{Gestional Age and Birth Weight}

Information on gestional age, and birth weight are summarized in Table 4. A tendency to deliver nearer to term is apparent, as well as a clear trend towards fewer small and big infants. Throughout the period Caesarian section was performed in $52.0 \%$ of deliveries, varying between $44.4 \%$ in 1969 and $62.5 \%$ in 1974 .

\section{Congenital Malformations}

Congenital malformations were registered 1.5 times more often in births to diabetic mothers than in the total birth population (Table 5). Higher rates were notable for malformations of the cardiovascular and nervous systems. The eight malformations in the nervous system were 2 anencephalic infants, 1 case of 
Table 4. Births to diabetic mothers in Norway 1967-1976. Birth weight and gestational age

\begin{tabular}{|c|c|c|c|c|c|c|c|c|}
\hline \multirow[b]{2}{*}{ Years } & \multicolumn{4}{|c|}{ Birth weight $(g)$} & \multicolumn{4}{|c|}{ Gestational age (weeks) } \\
\hline & $\begin{array}{l}<2500 \\
\%\end{array}$ & $\begin{array}{l}2500-4000 \\
\%\end{array}$ & $\begin{array}{l}>4000 \\
\%\end{array}$ & $\begin{array}{l}\text { Mean } \\
\text { weight } g\end{array}$ & $\begin{array}{l}<34 \\
\%\end{array}$ & $\begin{array}{l}34-37 \\
\%\end{array}$ & $\begin{array}{l}>37 \\
\%\end{array}$ & $\begin{array}{l}\text { Mean } \\
\text { age }\end{array}$ \\
\hline $1967-1968$ & 22.6 & 53.3 & 24.2 & 3232 & 16.1 & 64.5 & 16.1 & 35.5 \\
\hline 1969-1970 & 14.8 & 64.7 & 20.9 & 3324 & 13.5 & 63.2 & 20.7 & 36.0 \\
\hline 1971-1972 & 10.5 & 64.4 & 24.9 & 3454 & 10.5 & 62.7 & 23.4 & 36.1 \\
\hline 1973-1974 & 13.8 & 64.0 & 22.3 & 3328 & 8.5 & 63.5 & 25.6 & 36.2 \\
\hline $1975-1976$ & 10.4 & 70.7 & 18.9 & 3319 & 6.6 & 47.6 & 43.9 & 37.0 \\
\hline
\end{tabular}

The sum of percentages for gestational age is not 100 , as gestational age was not always known

micro-encephaly and meningo-myelocele combined, 2 others with microencephaly, 1 with meningoencephaly and 1 with congenital hydrocephalus. Details about caudal regression syndrome were not available. The numbers were too small to allow for an analysis of possible changes with time.

\section{Discussion}

A fall in perinatal mortality of births to diabetic mothers from about 18 to $6 \%$ over a 10 -year period is satisfactory. Taking into account that the Norwegian material includes the outcome of pregnancy down to 16 weeks of gestation a figure of $6 \%$ compares favourably with figures reported from specialized clinics in other countries $[4,5,6,7]$. A clinical analysis of results of diabetic pregnancies at Rikshospitalet has been reported earlier [8]. More Rikshospitalet cases are included in the present study: gestational diabetics, stillbirths down to 16 weeks gestation and patients from the years 1967-1969.

Comparable national figures are available only from Sweden [10] where perinatal mortality of births to diabetics was $7.3 \%$ in 1973 and $6.2 \%$ in 1974 . These rates are of the same order of magnitude as in Norway. The proportion of total births contributed by diabetics is, however, more than $50 \%$ higher in Sweden than in Norway. In Norway the proportion is less than 2 per 1000 births and in Sweden slightly above 3 . This difference may be due to varying reporting practices, for example more gestational diabetic pregnancies being diagnosed and registered in Sweden. Less probable, diabetics in Sweden may have a higher fertility. More interesting from an epidemiological point of view, there may be a difference in the prevalence of diabetes in the two countries. In this connection it is of interest that the use of insulin and oral antidiabetic drugs is $50 \%$ higher in Sweden than in Norway [11].
Table 5. Registered malformations in total births, and births of mothers with diabetes mellitus in Norway 1967-76

\begin{tabular}{|c|c|c|c|c|c|}
\hline \multirow[t]{3}{*}{$\begin{array}{l}\text { Type of malfor- } \\
\text { mation }\end{array}$} & \multicolumn{2}{|c|}{$\begin{array}{l}\text { All births } \\
(634996) \\
\text { Malformations }\end{array}$} & \multicolumn{3}{|c|}{$\begin{array}{l}\text { Births to diabetic mothers } \\
\text { (1035) } \\
\text { Malformations }\end{array}$} \\
\hline & \multirow[t]{2}{*}{$\begin{array}{l}\text { Num- } \\
\text { ber }\end{array}$} & \multirow[t]{2}{*}{$\begin{array}{l}\text { Rate } \\
\text { per } \\
1000\end{array}$} & \multirow[t]{2}{*}{$\begin{array}{l}\text { Num- } \\
\text { ber }\end{array}$} & \multirow[t]{2}{*}{$\begin{array}{l}\text { Rate } \\
\text { per } \\
1000\end{array}$} & $\begin{array}{l}\text { Observ- } \\
\text { ed rate }\end{array}$ \\
\hline & & & & & $\begin{array}{l}\text { Expect- } \\
\text { ed rate }\end{array}$ \\
\hline \multirow{4}{*}{$\begin{array}{l}\text { Cardiovascular } \\
\text { Nervous-system } \\
\text { Cleft palate } \\
\text { and/or lip } \\
\text { All other mal- } \\
\text { formations }\end{array}$} & 1356 & 2.1 & 11 & 10.6 & 5.0 \\
\hline & 1014 & 1.6 & 8 & 7.7 & 4.8 \\
\hline & 1180 & 1.9 & 2 & 1.9 & 1.0 \\
\hline & 15153 & 23.9 & 24 & 23.2 & 1.0 \\
\hline Total & 18703 & 29.5 & 45 & 43.5 & 1.5 \\
\hline
\end{tabular}

Congenital malformations are recorded more often in infants of diabetic mothers than in the general birth population $[6,12]$. In the present material, as in others, the frequency of cardiovascular and nervous system defects was especially high, and accounts for the excess malformation rate. There was no excess of cleft palate and/or cleft lip, as reported from Copenhagen [12], neither was the excess of congenital malformations in general as marked. The Copenhagen figures, however, were derived from a highly specialized hospital and may thus not be directly comparable to those compiled from a national birth registration system. On the other hand, frequencies of recorded congenital malformations in total births, at $2.9 \%$ in Norway and $2.8 \%$ in Copenhagen are similar.

The possibility of improving the outcome of pregnancies in diabetics became increasingly evident in the late 1960s and early 1970s [2, 4, 5, 6, 7, 8]. Improvements were obtained through strict metabolic control and intensive antenatal care at 
specialized clinics. At Rikshospitalet a regimen based on these principles was initiated in 1968-1970 [8]. The national figures presented in this report indicate that similar changes in the management of pregnant diabetics have been made in Norway in general during the period, resulting in deliveries nearer to term, more normal weight infants and lower perinatal mortality.

There is often a gap between what can be achieved in highly specialized medical centres and what happens in practice when considering therapeutic improvement in general. It is satisfactory, therefore, to be able to demonstrate that this gap has nearly been bridged as far as diabetic pregnancies in Norway are concerned. There is, however, room for further improvements. Compared to a perinatal death rate of $1.84 \%$ in $1975-1976$ in the total birth population of Norway, the death rate for births to diabetics is still too high. There remains also the problem of excess congenital malformations in births to diabetics.

\section{References}

1. Larsson J, Ludvigsson J (1974) Perinatal dödelighet ved diabetes graviditet. Läkartidningen 71: 155-157

2. Peel J (1972) A historical review of diabetes and pregnancy. Br J Obstet Gynaecol 79: 385-395

3. Vangen O, Molne K, Björo K (1972) Diabetes mellitus og svangerskap. Den perinatale mortalitet ved Rikshospitalet, Kvinneklinikken 1950-1970. Tidsskr Nor Laegeforen 92: 1313-1317
4. Drury M I, Greene A T, Stronge J M (1977) Pregnancy complicated by diabetes mellitus. A study of 600 pregnancies. Obstet Gynecol 49: 519-522

5. Essex N L, Pyke D A, Watkins P I, Brudenell J M, Gamsu H L (1973) Diabetic pregnancy. Br Med J IV: 89-93

6. Pedersen J (1977) The pregnant diabetic and her newborn. Munksgaard, Copenhagen

7. Möller E-B (1970) Studies in diabetic pregnancy. Thesis, Studielitteratur, Lund

8. Jervell J, Moe N, Skjæraasen J, Blystad W, Egge K (1979) Diabetes mellitus and pregnancy. Management and results at Rikshospitalet, Oslo 1970-1977. Diabetologia 16: 151-155

9. Bjerkedal T, Bakketeig L (1972) Medical registration of births in Norway 1967-1968. Some descriptions and analytical aspects. University of Bergen

10. Swedish National Board of Health and Welfare, H. S. (1977) 16. Medical birth registration in 1973 and 1974. Central Burea of Statistics, Stockholm

11. Bergman V, Elmes P, Halse M, Halvorsen T, Hood H, Lunde P KM, Sjöquist F, Wade OL, Westerholm B (1975) The measurement of drug consumption. Drugs for diabetes in Northern Ireland, Norway and Sweden. Eur J Clin Pharmacol 8: 83-89

12. Pedersen L, Mölsted L, Tygstrup I, Pedersen J (1964) Congenital malformations in newborn infants of diabetic women. Lancet I: $1124-1126$

Received: January 23, 1979

and in revised form: August 21, 1979

Jak Jervell

Department of Medicine

Rikshospitalet

Oslo 1

Norway 